ORIGINAL ARTICLE

\title{
Floral phenology, seed germination and hybrid plants of the Amerindian yam (Dioscorea trifida)
}

\author{
Patrick BEYERLEIN, Ângela M. S. MENDES, Henrique S. PEREIRA* 1 \\ Universidade Federal do Amazonas - UFAM, Av. Gal. Rodrigo O. J. Ramos 6200, Coroado, 69080-900, Manaus, AM, Brasil \\ * Corresponding author: hpereira@ufam.edu.br; (1) https://orcid.org/0000-0002-9113-1166
}

\begin{abstract}
The Amerindian yam (Dioscorea trifida) is a food plant native to the Amazon region. Several local varieties are cultivated by traditional family farmers for consumption and local trade. However, socioeconomic processes may be causing species genetic erosion. Knowledge about species sexual reproduction is essential for its conservation and genetic improvement. The objective of this study was to observe the floral phenology, to assess the germination and dormancy of seeds, to conduct controlled pollinations and to select hybrid plants of $D$. trifida with agronomic potential. Seed dormancy was confirmed and was broken by after-ripening at $28^{\circ} \mathrm{C}$ and $80 \% \mathrm{RH}$. We carried out controlled pollinations between local landraces and cultivated the resulting hybrid plants in the field. The new genotypes showed high phenotypic variability and tubers with new characteristics, which permitted the selection of genotypes with agronomic potential for further studies. The results contribute to the conservation of agrobiodiversity and genetic improvement for added value of Amazonian native food plants.
\end{abstract}

KEYWORDS: Amazonia, Dioscoreaceae, native food plant, controlled pollination, crossbreeding

\section{Fenologia floral, germinação de sementes e plantas híbridas de variedades locais de cará (Dioscorea trifida)}

\section{RESUMO}

O cará (Dioscorea trifida) é uma planta alimentícia nativa da Amazônia. Diversas variedades locais são cultivadas por agricultores familiares para consumo e comercializaçáo local. Porém, processos socioeconômicos podem estar causando a erosáo genética da espécie. O conhecimento sobre a reprodução sexuada da espécie é essencial para sua conservação e melhoramento genético. $\mathrm{O}$ estudo teve como objetivos observar a fenologia floral, estudar a germinação e a quebra de dormência de sementes, testar a viabilidade de polinizaçôes controladas e selecionar plantas híbridas de $D$. trifída com potencial agronômico. A dormência de sementes e a quebra da dormência após o armazenamento à $28^{\circ} \mathrm{C}$ e $80 \%$ UR foram comprovadas. As plantas híbridas obtidas a partir das polinizaçôes controladas foram cultivadas em condiçóes de campo. Os novos genótipos apresentaram alta variabilidade fenotípica e tubérculos com novas características, permitindo a seleção de genótipos com potencial agronômico para futuros estudos. Os resultados contribuem para a conservação da agrobiodiversidade e o melhoramento genético para agregar valor a plantas alimentícias nativas da Amazônia.

PALAVRAS-CHAVE: Amazônia, Dioscoreacaea, planta alimentícia nativa, polinização controlada, cruzamentos

\section{INTRODUCTION}

Amerindian yam (Dioscorea trifida L.) is a native Amazonian food plant (Clement et al. 2010), locally known in Brazil as cará. It is an important local crop for food security (Nascimento et al. 2015) and with high agronomic potential (Mollica et al. 2013; Pérez et al. 2011). Dioscorea trifida is a herbaceous, climbing, perennial, dioecious and allogamous plant, with high intraspecific genetic diversity (Nascimento et al. 2013). There is evidence that its center of origin is the Amazon, where it shows autotetraploidy in the cultivated form, and tri- or diploidy in the wild form (Bousalem et al.
2010). The species has high nutritional value and medicinal properties (Ramos-Escudero et al. 2010; Teixeira et al. 2013).

Despite their local relevance, yams are neglected and underutilized crops in Brazil (Siqueira et al. 2011). In the Brazilian state of Amazonas, traditional family farmers maintain numerous landraces of $D$. trifida for local consumption and also for selling at local markets. Germplasm materials are selected and then produced exclusively by vegetative propagation, which may have favorable fixation of certain agronomic characteristics and high capacity to tolerate biotic and abiotic stress. Yam growers may occasionally select hybrid plants that originated 
spontaneously from intervarietal crossbreeds from the seed bank in old swidden plots. Once chosen, the new phenotype is fixed through vegetative cloning, which is a common breeding method not only in yams, but also of other species of traditional fallow agriculture in the Amazon region, such as cassava (Manihot esculenta) (Martins 2005).

Castro et al. (2012) identified ten local landraces of $D$. trifida in its main cultivation region in the municipality of Caapiranga, in the Brazilian state of Amazonas, and that at least four landraces were no longer cultivated, and only known from the reports of local farmers. The cultivation of this species has been progressively abandoned or concentrated on only a few landraces, leading to genetic erosion and the loss of species diversity and increased extinction risk of landraces.

A germplasm collection was established in Amazonas and a study on in situ genetic resource management showed that local farmers cultivate their Amerindian yam plantations asexually by cloning (Beyerlein 2017). Knowledge about sexual reproduction is essential for agrobiodiversity conservation and genetic improvement. Therefore, our objectives were to study the floral phenology, and the germination and dormancy breaking of seeds of $D$. trifida, to conduct controlled pollinations and to select hybrid plants with agronomic potential.

\section{MATERIAL AND METHODS}

\section{Germination and dormancy-breaking}

Seeds were collected from 20 female $D$. trifida plants of five landraces of the germplasm collection at the experimental farm of the Federal University of Amazonas (UFAM) located

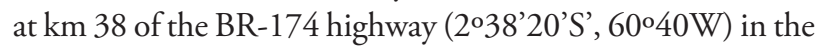
state of Amazonas, northern Brazil. The collection contains 153 accesses obtained in five municipalities of Amazonas state (Caapiranga, Manacapuru, Manaus, Humaitá and Boa Vista do Ramos) (Beyerlein and Pereira 2018). The seeds were stored in paper bags in a laboratory environment at 28 $\pm 3{ }^{\circ} \mathrm{C}$ air temperature and approximately $80 \%$ relative air humidity. The germination occurred in $20 \times 15 \times 5-\mathrm{cm}$ white plastic trays filled with sterilized substrate of thin vermiculite $(65-95 \%>1.2 \mathrm{~mm})$ in a germination chamber at $30 \pm 3^{\circ} \mathrm{C}$ air temperature and $90-95 \%$ relative air humidity.

Seed germination was evaluated as a function of storage time, as determined by the germination percentage, mean germination time and germination speed index, according to Santana and Ranal (2004). The germination percentage (G) was calculated as $G=(N / 100) \times 100$, where: $N=$ number of seeds germinated. The mean germination time (MGT) was obtained by daily counting of the germinated seeds and calculated as MGT $=\Sigma\left(n_{i} t_{i}\right) / \Sigma n_{i}$, where: $n_{i}=$ number of germinated seeds in the interval between each count; $t_{i}=$ time between the beginning of the germination and the $\mathrm{i}$-th count.
The germination velocity index (GVI) was considered as the sum of the number of germinated seeds per day, divided by the number of days between sowing and germination, and was calculated as GVI $=(\mathrm{G} 1 / \mathrm{N} 1)+(\mathrm{G} 2 / \mathrm{N} 2)+(\mathrm{G} 3 / \mathrm{N} 3)$ $+\ldots+(\mathrm{Gn} / \mathrm{Nn})$, where: $\mathrm{G} 1, \mathrm{G} 2, \mathrm{G} 3, \ldots, \mathrm{Gn}=$ number of seedlings in the first, second, third and last count; N1, N2, $\mathrm{N} 3, \ldots, \mathrm{Nn}=$ number of days of sowing to the first, second, third and last count.

A completely randomized design was used with nine treatments: recently collected seeds $(0-4$ days), and seeds stored for 15, 40, 72, 96, 120, 144, 184 and 224 days after collection. Each treatment consisted of four replicates of groups of 20 seeds, composed of equal proportions of each mother plant and landrace from the germplasm collection. Germination percentage, mean germination time and the germination speed index were compared among treatments using analysis of variance (ANOVA) followed by the Tukey test $(\mathrm{p}<0.05)$.

\section{Floral phenology}

The floral development of $D$. trifida plants cultivated in the germplasm collection was evaluated every two weeks during the flowering period. The fertilization rate of inflorescences with open pollination was estimated by randomly evaluating five inflorescences per plant of ten female plants, marking inflorescences with ribbons and calculating the fertilization rate based on the number of flowers and the number of fruits developed. Based on these estimations, six feminine and three masculine plants were selected to perform controlled pollinations between landraces with different tuber pulp color for the production of hybrid seeds (Table 1).

\section{Controlled pollinations and selection of hybrid plants}

When the first inflorescences appeared, they were covered with bags made of white tulle fabric. Female inflorescences were isolated to prevent pollen entry and flower pollination, and male inflorescences were isolated to avoid mixing with pollen from other plants. When synchrony occurred between the anthesis of female and male plants, male inflorescences were cut and taken to the female plants to perform pollination, touching the anthers with the stigmas.

Table 1. Main morphological traits of female and male parental landraces of Amerindian yam, Dioscorea trifida used for breedings.

\begin{tabular}{|c|c|c|c|c|}
\hline Landrace name & Code & Sex & Pulp color & Tuber shape \\
\hline Branco redondo & Brd & Female & White solid & Round \\
\hline Branco comprido I & Bcpl & Female & White solid & Elongated \\
\hline Ovo de cavalo & OC & Female & White solid & Oval \\
\hline Pé de elefante & PE & Female & White solid & Paw-like \\
\hline Branco casquinha roxa & $\mathrm{BCx}$ & Female & $\begin{array}{l}\text { White matrix with } \\
\text { purple near skin }\end{array}$ & Oblong \\
\hline Açai comprido & AÇcp & Male & Mixed purple matrix & Elongated \\
\hline Roxo comum & $R x$ & Male & Purple solid & Round \\
\hline Branco comprido II & Bcpll & Male & White solid & Elongated \\
\hline
\end{tabular}


After the pollination, the bags were closed again until the collection of the seeds. The efficiency of the isolation method was controled by confirming the inhibition of fruit formation in five bag-isolated inflorescences that were not pollinated. Mature fruits, as indicated by their brown color and open capsules, were collected. The seeds were stored in paper bags in a refrigerator at $4{ }^{\circ} \mathrm{C}$ for 15 days. The seeds were sown in 20 $\mathrm{x} 15 \times 5$-cm white plastic trays filled with sterilized substrate of thin vermiculite $(65-95 \%>1.2 \mathrm{~mm})$ and placed in the germinating chamber at $30 \pm 3{ }^{\circ} \mathrm{C}$ air temperature and $90-$ $95 \%$ relative air humidity.

Five days after germination, the seedlings were transplanted into individual planting tubes and placed in a plant nursery covered with shade net with 50\% shading. After two months the plants were transplanted into pits at a spacing of $1 \times 1 \mathrm{~m}$ in an experimental farm field. The soil type of the planting area was classified as a high-clay dystrophic yellow latosol. Soil correction and fertilization was carried out with $480 \mathrm{~g}$ $\mathrm{m}^{-2}$ dolomite lime $(25-30 \% \mathrm{CaO}$ and $15-20 \% \mathrm{MgO})$ and $3 \mathrm{~kg} \mathrm{~m}^{-2} \mathrm{dry}$ and homogenized chicken manure. The surface soil of an area of $1 \mathrm{~m}^{2}$ and $20 \mathrm{~cm}$ depth was mixed with the fertilizer and used to form the planting pit. The young plants were irrigated daily during the working days, from July untill August, i.e., during the dry season of 2015, which was particularly severe that year.

During the first month in the field, a formicide was applied to control an attack of leaf cutting ants of the genus Atta. The vegetation between the plants was cut every two months with a motorized brush cutter. The climbing support for each plant was made with three wooden sticks of $220 \mathrm{~cm}$ length. The aim of this system was to avoid contact between plants to facilitate the phenological observations of individual plants.

The development of the seedlings was evaluated for nine months by recording 13 morphological descriptors for tubers, 12 for stems and 14 for leaves, as suggested in Beyerlein and Pereira (2018). Sexual expression and seed production of the hybrids were also recorded. Hybrid plants that presented higher agronomic potential were incorporated into UFAM's collection.

\section{RESULTS}

\section{Germination and dormancy-break}

The recently collected seeds presented a significantly lower germination percentage than seeds stored for 15 days or longer, while there was no significant difference among storage times (Table 2). Therefore, a minimum of 15 days of storage time should be sufficient to maximize the percentage of germination. Mean germination time decreased significantly with storage time (Table 3 ), while the germination velocity index increased significantly with storage time (Table 4).
Table 2. Germination percentage of Amerindian yam, Dioscorea trifida seeds as a function of storage time. Values are the mean \pm SD, followed by the range. Different upper-case letters indicate statistical differences among treatments according to a Tukey test.

\begin{tabular}{lcc}
\hline Storage time (days) & Germination $(\%)$ & Coefficient of variation \\
\hline $0-4$ & $45.0 \pm 11.90(30-80)^{\mathrm{a}}$ & 52.90 \\
15 & $87.5 \pm 2.50(80-90)^{\mathrm{b}}$ & 5.71 \\
40 & $90.0 \pm 5.77(80-100)^{\mathrm{b}}$ & 12.83 \\
72 & $92.5 \pm 7.50(70-100)^{\mathrm{b}}$ & 16.22 \\
96 & $87.5 \pm 4.79(80-100)^{\mathrm{b}}$ & 10.94 \\
120 & $90.0 \pm 4.08(80-100)^{\mathrm{b}}$ & 9.07 \\
144 & $90.0 \pm 4.08(80-100)^{\mathrm{b}}$ & 9.07 \\
184 & $92.5 \pm 4.79(80-100)^{\mathrm{b}}$ & 10.35 \\
224 & $87.5 \pm 4.79(80-100)^{\mathrm{b}}$ & 10.94 \\
\hline
\end{tabular}

Table 3. Germination time of Amerindian yam, Dioscorea trifida seeds as a function of storage time. Values are the mean \pm SD, followed by the range. Different upper-case letters indicate statistical differences among treatments according to a Tukey test.

\begin{tabular}{lcc}
\hline Storage time (days) & Germination time (days) & Coefficient of variation \\
\hline $0-4$ & $58.90 \pm 4.90(49.0-71.3)^{\mathrm{a}}$ & 16.63 \\
15 & $53.78 \pm 2.38(46.8-57.5)^{\mathrm{a}}$ & 8.85 \\
40 & $38.70 \pm 3.94(34.1-50.5)^{\mathrm{b}}$ & 20.38 \\
72 & $28.98 \pm 1.38(24.9-30.9)^{\mathrm{bc}}$ & 9.53 \\
96 & $28.55 \pm 1.03(25.7-30.6)^{\mathrm{bc}}$ & 7.20 \\
120 & $33.00 \pm 2.97(28.4-41.1)^{\mathrm{bc}}$ & 18.00 \\
144 & $27.70 \pm 1.34(24.9-31.1)^{\mathrm{bc}}$ & 9.68 \\
184 & $25.83 \pm 0.81(24.1-28.0)^{\mathrm{c}}$ & 6.28 \\
\hline 224 & $21.13 \pm 0.55(20.3-22.7)^{\mathrm{c}}$ & 5.25 \\
\hline
\end{tabular}

Table 4. Germination velocity index of Amerindian yam, Dioscorea trifida seeds as a function of storage time. Values are the mean $\pm S D$, followed by the range Different upper-case letters indicate statistical differences among treatments according to a Tukey test.

\begin{tabular}{lcc}
\hline Storage time (days) & Germination velocity index & $\begin{array}{c}\text { Coefficient } \\
\text { of variation }\end{array}$ \\
\hline $0-4$ & $0.08 \pm 0.02(0.05-0.14) \mathrm{a}$ & 52.99 \\
15 & $0.17 \pm 0.01(0.14-0.20) \mathrm{ab}$ & 12.54 \\
40 & $0.25 \pm 0.03(0.17-0.31) \mathrm{bc}$ & 24.23 \\
72 & $0.30 \pm 0.01(0.29-0.35) \mathrm{bcd}$ & 8.03 \\
96 & $0.32 \pm 0.02(0.28-0.36) \mathrm{c}$ & 13.69 \\
120 & $0.29 \pm 0.03(0.23-0.36) \mathrm{cd}$ & 20.85 \\
\hline 144 & $0.34 \pm 0.01(0.32-0.38) \mathrm{d}$ & 8.74 \\
184 & $0.37 \pm 0.02(0.33-0.41) \mathrm{e}$ & 9.86 \\
\hline 224 & $0.43 \pm 0.02(0.40-0.46) \mathrm{e}$ & 7.84 \\
\hline
\end{tabular}




\section{Floral phenology}

The phenophases were determined mainly by the rainfall. The tuber sprouting started in the rainy season in December 2013 within a period of 30 to 48 days, except for one landrace that took three to four weeks more to start sprouting. Most landraces started inflorescence development in the next year, in April, six months after tuber planting, and finished flowering in July. One landrace began to flower in early March, one month before the others, and another landrace did not develop inflorescences. The drying of the leaves and branches occurred with the beginning of the dry season, in August 2014, and seed and tuber ripening occurred from August to September.

The natural pollination of D. trifida is xenogamic. The flowers smell well and we regularly observed microbees landing and flying from flower to flower. A possible pollinator visiting frequently the flowers was photographed and identified as a micro-bee of the genus Melipona, possibly $M$. varia. Furthermore, ants were frequently observed on inflorescences, moving between flowers. Possible insect pollinators were observed by Henry (1967), who recorded visiting insects on the flowers of $D$. trifida that belonged to Formicidea, Vespidae, Chalcididae, Curculionidae, Lamprydae, Chrysomelidae, Muscidae and Tachinidae.

The average fertilization rate of the plants evaluated with open pollination varied from 25 to $90.8 \%$ with an overall average of $61.7 \%$. The average number of seeds per fruit varied from 2.9 to 5.7 with an overall average of 4.8 , showing high production capacity of seeds.

\section{Controlled pollinations and selection of hybrid plants}

Controlled pollination was easily conducted. The isolated male flowers opened in the morning and began to dispose the pollen about half an hour later. The floral anthesis occurred irregularly over a period of two to seven days. The female flowers remained open and presumably susceptible to pollination for several days. The fruits matured at the beginning of the dry season, three to four months after pollination.

From a total of 159 seeds, originated from seven crosses, 124 germinated, resulting in an overall germination rate of $78 \%$. Of the 124 seedlings, 108 plants survived in the greenhouse and were transplanted. Plants suffered water stress due to a lack of irrigation on weekends and, probably due to this, only 55 plants from seven crosses survived. The hybrid plants of crosses 1, 2, 3 and 4 (Table 5) had a 1:1 female to male ratio and a flowering percentage of $70 \%$. Crosses 5, 6 and 7 produced only plants with female flowers.

Hybrid plants had variable flowering and fruiting rates, seed production, leaf shapes, and, particularly, tuber shape and pulp color in all seven crosses (Figure 1, Table 5). We did not observe the occurrence of diseases or pests in any of the F1 hybrids. Only in the $7^{\text {th }}$ cross both parents were white pulp landraces, and the only surviving plant also shown solid white pulp color (Table 5, Figure 1b). No F1 plant presented tubers with round shape and only a few had tubers with regular shape, i.e., more uniform in size and without ramifications (Table 5).

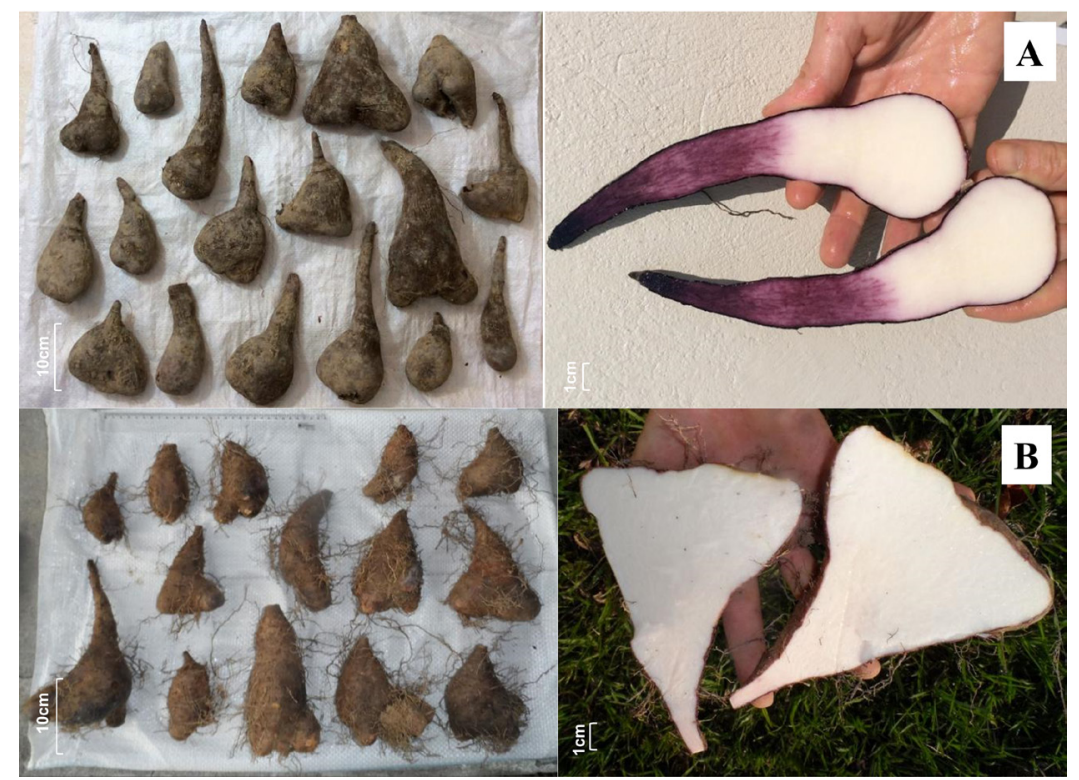

Figure 1. Whole and sectioned tubers of hybrid Amerindian yam, Dioscorea trifida. A - Cross 2 (female of branco comprido landrace, with white pulp x male of açaí comprido landrace, with mixed purple pulp); B - Cross 7 (female of branco casquinha roxa landrace, with white pulp x male of branco comprido landrace, also with white pulp). This figure is in color in the electronic version. 
Table 5. Main morphological traits of hybrid plants of Dioscorea trifida from controlled pollination. F1 = number of surviving F1 plants.

\begin{tabular}{|c|c|c|c|c|c|c|c|c|c|}
\hline \multirow{2}{*}{ Cross } & \multirow{2}{*}{ Female } & \multirow{2}{*}{ Male } & \multirow{2}{*}{ F1 } & \multicolumn{3}{|c|}{ Tuber shape } & \multicolumn{3}{|c|}{ Pulp color } \\
\hline & & & & Oval & Elongated & Paw-like & Solid white & Solid purple & Mixed or segmented \\
\hline 1 & Brd & AÇcp & 20 & + & & + & & & + \\
\hline 2 & Bcpl & $A C ̧ c p$ & 12 & + & + & + & & & + \\
\hline 3 & OC & AÇсp & 8 & + & & & & & + \\
\hline 4 & Brd & $\mathrm{Rx}$ & 7 & + & + & & + & + & + \\
\hline 5 & $B c x$ & AÇcp & 1 & & & & & & + \\
\hline 6 & $P E$ & $A C ̧ c p$ & 6 & & + & + & & & + \\
\hline 7 & $\mathrm{BCx}$ & Bcpll & 1 & & & + & + & & \\
\hline
\end{tabular}

\section{DISCUSSION}

The fruit yield obtained for $D$. trifida in this study was only slightly lower than that obtained for Dioscorea alata L. (Abraham et al. 1986), and substantially higher than that obtained for white yam, Dioscorea rotundata Poir. (Akoroda 1985). The high germination vigor of D. trifida seeds after a relatively short storage time, as well as the decrease of germination time with seed storage time, indicate the occurrence of post-harvest seed ripening, which contributed significantly to a faster germination. The results support the occurrence of seed dormancy and the breaking of dormancy through after-ripening storage in $D$. trifida.

Seed dormancy was defined by Finch-Savage and LeubnerMetzger (2006) as "a block to the completion of germination of an intact viable seed under favourable conditions". Through this adaptation, germination is programmed to avoid unfavorable climatic conditions for subsequent plant establishment and reproductive growth (Penfield 2017). Dioscorea trifida seed dormancy was broken faster than in other species of Dioscorea, such as D. rotundata, which has a dormancy period of three to four months after harvest and a relatively low germination rate due to embryo or endosperm development issues (Sadik 1976). An even longer dormancy time was observed for $D$. composita Hemsl., which broke dormancy only after storage for nine months (Viana and Felippe 1990). These results suggest that $D$. trifida presents a physiological dormancy, as do other Dioscorea species, such as the medicinal D. villosa L. (Langhu and Deb 2014). Physiological dormancy is caused by hormones that prevent germination in the absence of specific environmental conditions, as opposed to morphological dormancy in which the embryo remains underdeveloped at maturity (Penfield 2017). Viability of seedborn plants may explain how local variability of $D$. trifida has been accidentally amplified by traditional farmers.

The 55 hybrid plants of seven crosses that survived the greenhouse phase had eight of the 12 originally tested landraces as parent plants. Thus the hybrid plants were halfsibling groups, as they shared the same maternal or paternal parent. Henry (1967) also observed a sex ratio of 1:1 in populations of $D$. trifida plants with a flowering ratio over $60 \%$. The latter author observed some hermaphrodite plants, which could not be observed in the plants in our study.

With the exception of the plant from the $7^{\text {th }}$ cross, all remaining hybrids had parents with different pulp color matrices, i.e., a predominantly white female parent and a predominantly purple male parent. This may explain the new segmented pulp color patterns presented by most hybrid plants (Figure 1a). The $4^{\text {th }}$ cross was the only one that produced both solid white and purple F1 plants and this may result from the fact that both parents had pulps with solid colors, which is the pulp-color characteristic preferred by both farmers and consumers.

\section{CONCLUSIONS}

Amerindian yam, Dioscorea trifida seed dormancy is broken in response to an after-ripening dry storage period as short as 15 days. Our results on flowering, controlled pollination, seed production and germination indicate that the species has the capacity to produce a large quantity of viable seeds, providing opportunities for selective breeding programs through sexual reproduction and also for breeding methods. Among our crosses between five female and three male landraces, one between a white-solid pulp-color female and a purple-solid pulp-color male produced the most promising F1 plants, with solid-color and uniform tubers, which are characteristics preferred by farmers and consumers.

\section{ACKNOWLEDGMENTS}

We are grateful to the Amazonian farmers who cultivate the Amerindian yam and maintain its agrobiodiversity, and for their collaboration in this research. We are also grateful to the staff of the experimental farm of Universidade Federal do Amazonas (UFAM) for their support. Special thanks to Fundaçáo de Amparo à Pesquisa do Estado do Amazonas (FAPEAM) for the doctoral scholarship to the first author.

\section{REFERENCES}

Akoroda, M.O. 1985. Pollination management for controlled hybridization of white yam. Scientia Horticulturae, 25: 201-209. 
Abraham, K.; Nair, S.C.; Sreekumari, M.T.; Unnikrishnan, M. 1986. Weed set and seedling variation in greater yam (Dioscorea alata L.). Euphytica, 35: 337-343.

Bernard, H.R. 2006. Research methods in anthropology: qualitative and quantitative approaches. 4th ed. Altamira Press, Lanham, 192p.

Beyerlein, P. 2017. Agrobiodiversidade do cará (Dioscorea trifida L.) e sua conservação in-situ em Caapiranga, Amazonas. Doctoral thesis, Universidade Federal do Amazonas, Brazil. 131p. (https:// tede.ufam.edu.br/handle/tede/5717)

Beyerlein, P.; Pereira, H.S. 2018. Morphological diversity and identification key for landraces of the Amerindian yam in central Amazon. Pesquisa Agropecuária Brasileira, 53: 405-418.

Bousalem, M.; Viader, V.; Mariac, V.; Gomez, R.; Hochu, I.; Santoni, S.; David, J. 2010. Evidence of diploidy in the wild Amerindian yam, a putative progenitor of the endangered species Dioscorea trifida (Dioscoreaceae). Genome, 53: 371-383.

Castro, A.P.; Fraxe, T.J.P.; Pereira, H.S.; Kinupp, V.F. 2012. Etnobotânica das variedades locais do cará (Dioscorea spp.) cultivados em comunidades no município de Caapiranga, estado do Amazonas. Acta Botanica Brasilica, 26: 658-667.

Clement, C.R.; Cristo-Araújo, M.; d'Eeckenbrugge, G.C.; Pereira. A.A.; Picanço-Rodrigues, D. 2010. Origin and domestication of native Amazonian crops. Diversity, 2: 72-106.

Finch-Savage, W.E.; Leubner-Metzger, G. 2006. Seed dormancy and the control of germination. New Phytologist, 171: 501-523.

Henry, V.C.R. 1967. Studies on botanical and agronomic characteristics in cush-cush (Dioscorea trifida L.). Doctoral thesis, McGill University, Canada. 189p.

Langhu, T.; Deb, C.R. 2014. Studies on reproductive and seed biology of Dioscorea villosa

Linnaeus (Dioscoreaceae): a rare medicinal plant in NE India. Pleione, 8: $251-257$.

Martins, P.S. 2005. Dinâmica evolutiva em roças de caboclos amazônicos. Estudos Avançados, 19: 209-220.

Mollica, J.Q.; Cara, D.C.; D’Auriol, M.; Oliveira, V.B.; Cesar, I.C.; Brandão, M.G. 2013. Anti-inflammatory activity of American yam Dioscorea trifida Lf in food allergy induced by ovalbumin in mice. Journal of Functional Foods, 5: 1975-1984.

Nascimento, W.F.; Rodrigues, J.F.; Koehler, S.; Gepts, P.; Veasey, E.A. 2013. Spatially structured genetic diversity of the Amerindian yam (Dioscorea trifida L.) assessed by SSR and ISSR markers in Southern Brazil. Genetic Resources and Crop Evolution, 6: 2405.

Nascimento, W.F.; Siqueira, M.V.B.M.; Ferreira, A.B.; Ming, L.C.; Peroni, N.; Veasey, E.A. 2015. Distribution, management and diversity of the endangered Amerindian yam (Dioscorea trifida L.). Brazilian Journal of Biology, 75: 104-113.

Penfield, S. 2017. Seed dormancy and germination. Currrent Biology, 27: R874-R878.

Pérez, E.; Gibert, O.; Rolland-Sabaté, A.; Segovia, X.; Sánchez, T.; Reynes, M.; Dufour, D. 2011. Evaluation of the functional properties of promising Dioscorea trifida L. waxy starches for food innovation. International Journal of Carbohydrate Chemistry, 2011: 1-7.

Ramos-Escudero, F.; Santos-Buelga, C.; Pérez-Alonso, J.J.; Yáñez, J.A.; Dunñas, M. 2010. HPLC-DAD-ESI/MS identification of anthocyanins in Dioscorea trifida L. yam tubers (purple sachapapa). European Food Research Technology, 230: 745-752.

Sadik, S. 1976. A review of sexual propagation for yam improvement. In: Proceedings of the Fourth Symposium of the International Society for Tropical Root Crops, IDRC, Ottawa, Canada, p.40-44.

Santana, D.G.; Ranal, M.A. 2004. Análise da germinação: um enfoque estatístico. Editora UnB, Brasília, 247p.

Siqueira, M.V.B.M. 2011. Yam: a neglected and underutilized crop in Brazil. Horticultura Brasileira, 29: 16-20.

Teixeira, A.P.; Oliveira, I.M.A.; Lima, E.S.; Matsuura, T. 2013. The use of purple yam (Dioscorea trifida) as a health-promoting ingredient in bread making. Journal of Research in Biology, 3: 747-758.

Viana, A.M.; Felippe, G.M. 1990. Effects of storage on germination of Dioscorea composita (Dioscoreaceae) seeds. Economic Botany, 44: 311-317.

Willis, C.G.; Baskin, C.C.; Baskin, J.M.; Auld, J.R.; Venable, D.L.; Cavender-Bares, J.; et al. 2014. The evolution of seed dormancy: environmental cues, evolutionary hubs, and diversification of the seed plants. New Phytologist, 203: 300-309.
RECEIVED: 22/08/2018
ACCEPTED: 20/05/2019
ASSOCIATE EDITOR: Wolfgang Stuppy 